ISSN 1678-3921

Journal homepage: www.embrapa.br/pab

For manuscript submission and journal contents, access: www.scielo.br/pab
Ibrahim Mubarak ${ }^{(1)}$ (D)

1) Atomic Energy Commission of Syria, Department of Agriculture, PO Box 6091, Damascus, Syria.

E-mail: ascientific10@aec.org.sy

$\bowtie$ Corresponding author

Received

October 24, 2019

Accepted

March 05, 2020

How to cite

MUBARAK, I. Triple-row system with a wider drip-line lateral spacing for two drip-irrigated sweet corn cultivars. Pesquisa Agropecuária Brasileira, v.55, e01684, 2020. DOI: https://doi. org/10.1590/S1678-3921.pab2020.v55.01684.

\section{Triple-row system with a wider drip-line lateral spacing for two drip-irrigated sweet corn cultivars}

\begin{abstract}
The objective of this work was to evaluate the use of both singleand triple-row production systems in two drip-irrigated sweet corn cultivars under dry Mediterranean climate conditions. A two-year field experiment (2017 and 2018) was carried out in clay loam soil. The following three combinations spacing between crop rows and drip-line lateral spacing, with three replicates for each cultivar, were applied: single rows at $75 \mathrm{~cm}$ spacing, with one drip-line lateral spacing for each crop row; single rows at $75 \mathrm{~cm}$ row spacing, with one drip-line lateral spacing for three crop rows; and triple rows, $37.5 \mathrm{~cm}$ apart, on $225 \mathrm{~cm}$ centers, with one drip-line lateral spacing for each triple row. The responses of both cultivars were similar. In addition, husked cob yield and irrigation water use efficiency (IWUE) significantly reduced as the drip-line lateral spacing increased in single rows. Yield loss was $35.2 \%$ in relation to the $75 \mathrm{~cm}$ spacing. However, when the triple-row system with 225 $\mathrm{cm}$ drip-line lateral spacing was adopted, yield and IWUE were noticeably improved, and the yield loss was moderated to $16 \%$, due to the improvement in soil water conditions in the triple rows. For improved yield and IWUE, the combination of triple rows with the $225-\mathrm{cm}$ drip-line lateral spacing is an efficient drip-irrigated planting pattern for sweet corn production in dry Mediterranean climate conditions.
\end{abstract}

Index terms: Zea mays, clay loam soil, husked cob yield, irrigation water use efficiency, single-row system.

\section{Sistema de fileira tripla com maior espaçamento lateral para duas cultivares de milho-doce irrigadas por gotejamento}

Resumo - O objetivo deste trabalho foi avaliar o uso de sistemas de produção em fileira única e tripla para duas cultivares de milho-doce irrigadas por gotejamento, em condições de mediterrâneo seco. Um experimento de campo foi realizado por dois anos (2017 e 2018) em solo argiloso. As seguintes três combinações de espaçamento entre culturas e espaçamentos laterais foram utilizadas, com três repetições para cada cultivar: linhas simples com espaçamento de $75 \mathrm{~cm}$ nas linhas, com uma lateral para cada linha de cultivo; linhas simples com espaçamento entre linhas de $75 \mathrm{~cm}$, com uma lateral, para três linhas de cultivo; e linhas triplas, separadas por $37,5 \mathrm{~cm}$, em centros de $225 \mathrm{~cm}$, com uma lateral para cada linha tripla. As respostas de ambas as cultivares foram semelhantes. Além disso, o rendimento da espiga descascada e a eficiência de uso da água de irrigação (IWUE) reduziram-se significativamente à medida que o espaçamento lateral aumentava em fileiras simples. A perda de rendimento foi de $35,2 \%$ em relação ao espaçamento de 
$75 \mathrm{~cm}$. No entanto, quando o sistema de linha tripla, com espaçamento lateral de $225 \mathrm{~cm}$, foi adotado, o rendimento e o IWUE melhoraram visivelmente, e a perda de rendimento foi moderada para $16 \%$, em razão da melhoria nas condições da água no solo, nas linhas triplas. Para melhores rendimento e IWUE, a combinação de linhas triplas com o espaçamento lateral de $225 \mathrm{~cm}$ é um padrão eficiente para o plantio irrigado por gotejamento de milho-doce, em condições de clima mediterrâneo seco.

Termos para indexação: Zea mays, solo argiloso, rendimento de espigas descascadas, eficiência de uso da água de irrigação, sistema de fileira única.

\section{Introduction}

Crop production and in-field water use efficiency have been proved to be enhanced under drip-irrigation methods compared with others (Goyal, 2014, 2015; Venot et al., 2017). Nonetheless, one of the main disadvantages of this technique is its high initial cost of installation, limiting its widespread adoption by the farmers. The pipes account for about $45 \%$ of the total cost, but only $30 \%$ for the irrigation control head (Phocaides, 2007).

In this context, reducing the number of drip-line laterals per unit area, by increasing the drip-line lateral spacing would be one of the most valuable practices for reducing the total costs (Himanshu et al., 2012; Couto et al., 2013; Chen et al., 2015; Zhou et al., 2017, 2018; Al-Hurmuzi \& Topak, 2018). However, because of the lack of rainfall in dry regions, and the inability of drip irrigation with wider drip-line lateral spacing to wet the soil surface away from drip-line laterals, seed germination may be a problem, and the early growth period could be limited by water stress, especially in sandy soils and in soils with large cracks, which restricts the horizontal infiltration of drip irrigation as capillary barrier (Qi et al., 2020). In this case, excessive pre-planting irrigations will not be feasible, and a backup irrigation system is required to support seed germination. Even in regions showing reliable rainfall, the yield reduction due to row-to-row variation may increase under wider lateral spacing (Lamm et al., 1997; Bozkurt et al., 2006; Chen et al., 2015; Fischer et al., 2019; Lv et al., 2019).

The multiple-row pattern is a production system for planting crops in strips (ranges or bands) of two or more rows, and the spaces between the adjacent strips remain unplanted. The multiple-row production system has been used as a technique to improve crop yield in comparison to single-row system, for soybean (Bruns, 2011), sugarcane (Ehsanullah et al., 2011), groundnut (Mandal et al., 2019), onion and tomato (Wondatir \& Belay, 2020), and corn (Bruns et al., 2012; Al-Hurmuzi \& Topak, 2018). In multi-rows, the speed of canopy closure improves the light interception and, consequently, the plant growth rates, besides reducing weed competition and soil-water evaporation (Fanadzo et al., 2010; Liu et al., 2011; Saudy, 2013; Williams \& Boydston, 2013).

The use of twin rows for drip-irrigated sweet corn production has been documented (Al-Hurmuzi \& Topak, 2018; Mubarak, 2020). However, to the best of our knowledge, there is almost none available information on the combined use of triple rows with wider drip-line lateral spacing for sweet corn production. Under such planting arrangement, crop rows are brought closer and grouped into strips with triple rows, and one drip-line lateral serves each strip. Using one drip-line lateral for three crop rows reduces the number of drip-line laterals needed per unit area and, therefore, its initial cost, to a third, as compared with the conventional planting/drip-line pattern (one drip-line lateral for each crop row). Herein, a triplerow system is proposed for drip-irrigated sweet corn crop. Plants are planted in triple-rows, with one dripline lateral located at the center of each strip. Under such planting and irrigation pattern, crop rows are closer to the wetting zone (drip-line laterals) than those of single-rows in the same drip-line lateral spacing. Therefore, drip-irrigated triple rows may improve the crop yield by reducing the row-to-row variation, so that crop production might be not insufficiently diminish to justify the high cost of a conventional, closer dripline lateral spacing.

The objective of this work was to evaluate the use of both single- and triple-row production systems in two drip-irrigated sweet corn cultivars under the dry Mediterranean climate conditions.

\section{Materials and Methods}

Field experiments were implemented during 2017 and 2018 at the Agricultural Experiment Station, Deir Al-Hajar, Damascus Countryside in Syria $\left(33^{\circ} 20^{\prime} \mathrm{N}, 36^{\circ} 26^{\prime} \mathrm{E}\right.$, at $600 \mathrm{~m}$ altitude). The hot and dry steppe climate, BSh climate, according to the 
Köppen-Geiger's climate classification, dominates the study area (Kottek et al., 2006). The yearly potential evapotranspiration $\left(\mathrm{ET}_{0}\right)$ exceeds 2,000 $\mathrm{mm}$ (estimated using the FAO Penman-Monteith equation), and the annual precipitation is about 120 $\mathrm{mm}$. Some meteorological data of the study site, which were collected during both tested growing seasons, and those for the past 20-year average are presented (Table 1). The soil is most likely Aridisols (classified as Camborthids), with a clay loam texture of $295 \mathrm{~g} \mathrm{~kg}^{-1}$ clay, $427 \mathrm{~g} \mathrm{~kg}^{-1}$ silt, $278 \mathrm{~g} \mathrm{~kg}^{-1}$ sand, $1.35 \mathrm{~g} \mathrm{~cm}^{-3}$ bulk density, and $<1 \%$ organic matter, according to the wet oxidation method (Jackson, 1985).

Field experiments were carried out with the sweet corn (Zea mays L.) cultivars 'Silver Queen' and 'White Kokab' (a local cultivar). Two different row production systems with two different drip-line lateral spacing (75 and $225 \mathrm{~cm}$ ) were studied for each cultivar. The experiments were arranged in a split-plot design with two corn cultivars as main plots, and three combinations

Table 1. Some meteorological parameters for the study site during both growing seasons 2017 and 2018, and the average of last 20 years.

\begin{tabular}{|c|c|c|c|c|c|}
\hline Year & Parameter & April & May & June & July \\
\hline \multirow{6}{*}{2017} & $\mathrm{~T}_{\min }\left({ }^{\circ} \mathrm{C}\right)$ & 9.7 & 14.4 & 17.2 & 20.6 \\
\hline & $\mathrm{T}_{\max }\left({ }^{\circ} \mathrm{C}\right)$ & 26.2 & 31.6 & 35.7 & 40.6 \\
\hline & $\mathrm{T}_{\text {mean }}\left({ }^{0} \mathrm{C}\right)$ & 19.2 & 24.9 & 28.4 & 31.1 \\
\hline & RH (\%) & 63.1 & 57.9 & 56.3 & 56.0 \\
\hline & $\mathrm{ET}_{0}\left(\mathrm{~mm}\right.$ day $\left.^{-1}\right)$ & 5.7 & 7.6 & 9.0 & 10.3 \\
\hline & Rain (mm) & 0.0 & 0.0 & 0.0 & 0.0 \\
\hline \multirow{6}{*}{2018} & $\mathrm{~T}_{\min }\left({ }^{0} \mathrm{C}\right)$ & 10.0 & 15.6 & 18.2 & 19.8 \\
\hline & $\mathrm{T}_{\max }\left({ }^{\circ} \mathrm{C}\right)$ & 27.2 & 31.5 & 34.6 & 36.9 \\
\hline & $\mathrm{T}_{\text {mean }}\left({ }^{\circ} \mathrm{C}\right)$ & 19.9 & 25.7 & 27.7 & 28.8 \\
\hline & RH (\%) & 54.8 & 51.5 & 59.6 & 55.6 \\
\hline & $\mathrm{ET}_{0}\left(\mathrm{~mm}\right.$ day $\left.^{-1}\right)$ & 6.8 & 7.8 & 8.8 & 10.3 \\
\hline & Rain (mm) & 14 & 0.0 & 0.0 & 0.0 \\
\hline \multirow{6}{*}{$\begin{array}{l}\text { Last } 20 \\
\text { years }\end{array}$} & $\mathrm{T}_{\min }\left({ }^{\circ} \mathrm{C}\right)$ & 10.1 & 14.1 & 17.6 & 19.3 \\
\hline & $\mathrm{T}_{\max }\left({ }^{\circ} \mathrm{C}\right)$ & 25.3 & 30.4 & 35.0 & 37.4 \\
\hline & $\mathrm{T}_{\text {mean }}\left({ }^{\circ} \mathrm{C}\right)$ & 18.1 & 23.6 & 27.7 & 29.4 \\
\hline & RH (\%) & 60.9 & 56.5 & 56.3 & 60.7 \\
\hline & $\mathrm{ET}_{0}\left(\mathrm{~mm}\right.$ day $\left.^{-1}\right)$ & 5.6 & 7.5 & 9.4 & 10.4 \\
\hline & Rain (mm) & 5.9 & 4.2 & 0.0 & 0.0 \\
\hline
\end{tabular}

$\mathrm{T}_{\min }$ : minimum temperature, $\mathrm{T}_{\max }$ : maximum temperature, $\mathrm{T}_{\text {mean }}$ : average temperature, $\mathrm{RH}$ : relative air humidity, $\mathrm{ET}_{0}$ : reference evapotranspiration. of crop rows and drip-line lateral spacing as subplots, with three replicates. The treatments were evaluated as the following description. Treatment DS75 was performed in single-rows at $75 \mathrm{~cm}$, with one drip-line lateral for each crop row, and the experimental unit contained five crop rows of $75 \mathrm{~cm}$ spacing and dripline laterals. DS225 was performed in single-rows at $75 \mathrm{~cm}$, with one drip-line lateral for three crop rows located at the central row; therefore, the drip-line lateral spacing was $225 \mathrm{~cm}$; its experimental unit contained nine $75 \mathrm{~cm}$ rows, and three $225 \mathrm{~cm}$ drip-line laterals. DS225-T was performed in a triple-row system, with rows brought closer $(37.5 \mathrm{~cm})$ and grouped into strips (ranges or bands) with triple rows. In other words, corn was planted in triple rows with $37.5 \mathrm{~cm}$ apart, in 225 $\mathrm{cm}$ centers. The experimental unit contained three strips spaced at $225 \mathrm{~cm}$ apart, and one drip-line lateral served each triple row.

The length of each experimental unit was $5 \mathrm{~m}$. The number of crop rows per hectare and, therefore, the plant density (about 67,000 plants ha ${ }^{-1}$ ) were maintained equal for all treatments.

The field was traditionally prepared, that is, disked and ploughed before sowing. A sufficient spacing (about $2 \mathrm{~m}$ ) was maintained between experimental units to minimize water intervention among treatments. Corn was sown on April 18 ${ }^{\text {th }}$ in 2017, and on April $3^{\text {rd }}$ in 2018. Another lateral move irrigation system, which is available in the experimental station, was used early in each season, in order to germinate the seed. It was also used two times during the $1^{\text {st }}$ month, with $100 \mathrm{~mm}$ water applied. After that, the drip irrigation treatments were applied. Lateral drip-lines of $16 \mathrm{~mm}$ diameter, with a built-in $40 \mathrm{~cm}$ emitter spacing of $4 \mathrm{~L}$ per hour discharge were used. The experimental field was fertilized in early winter, before each cropping season, with $46 \mathrm{~kg} \mathrm{ha}^{-1} \mathrm{P}_{2} \mathrm{O}_{5}$ as triple super phosphate. However, $\mathrm{N}$ fertilizer as urea $\left(150 \mathrm{~kg} \mathrm{ha}^{-1}\right.$ $\mathrm{N})$ was surface-applied as solution, in two equally split applications: at the sowing day, and two weeks later. Thus, all plants received the same quantities of both chemical fertilizers.

The initial, development, mid-season and late season growth stages for sweet corn crop were 20, 30, 40, and 10 days, respectively (Allen et al., 1998). The crop coefficient values were $0.3,1.15$, and 1.05 , respectively, for initial, mid-season and late season periods. Daily crop water requirement (crop evapotranspiration, 
ETc) was calculated by multiplying the daily $\mathrm{ET}_{0}$ by $\mathrm{Kc}$ for each growth stage. The weekly sum of daily ETc values was used to adjust the schedule for the next week. All treatments received the same irrigation water depth (amount per unit area): about 753 in the 2017 season, and $700 \mathrm{~mm}$ in the 2018 season. However, because of different drip-line lateral spacing (DLLS), the treatments differed for irrigation durations, as calculated by the equation

$$
\begin{aligned}
& \text { Irrigation time }(\mathrm{hr}) \\
& =\frac{\mathrm{DLLS}(\mathrm{cm}) \times \text { emitter spacing }(\mathrm{cm}) \times \text { irrigation water depth }(\mathrm{mm})}{10,000 \times \text { emitter rate }(\mathrm{L} / \text { hour })}
\end{aligned}
$$

The durations of the total drip irrigation applied to the DS75, DS225, and DS225-T treatments were 49, 147, and 147 hours in the 2017 season, and 45, 135, and 135 hours in the 2018 season, respectively.

For the monitoring of soil-water content $[\theta(\mathrm{z})]$, access tubes of in-situ calibrated neutron scattering probe (Model 503 Hydroprobe, CPN International, Martinez, CA, USA) were installed in the crop rows only for 'Silver Queen' plots. Measurements were conducted about 72 hours after each irrigation. For both DS225 and DS225-T treatments, two soil profiles were probed: the nearest and the furthest rows from drip-line laterals. The total soil-water storage (SWS) from the soil surface to a specific depth was calculated as follows:

$$
\mathrm{SWS}=\int_{0}^{\mathrm{Zm}} \theta(\mathrm{z}) \mathrm{dz}
$$

in which: $\mathrm{z}$ is the soil depth (m); $\theta$ is the soil-water content $\left(\mathrm{cm}^{3} \mathrm{~cm}^{-3}\right)$; and $\mathrm{Zm}$ is the root zone depth (1.2 m).

In order to check soil-water stress in the root zone, the function for water stress response as suggested by Feddes et al. (1978) was used. That function is characterized by several root-water uptake parameters $\left(\mathrm{h}_{2}, \mathrm{~h}_{3}\right.$, and $\left.\mathrm{h}_{4}\right)$. Root-water uptake is considered optimal between two pressure heads $h_{2}$ and $h_{3}$, whereas for soil-water pressure heads between $h_{3}$ and $h_{4}$, water uptake decreases. It is also considered to be zero for soil-water pressure heads less than the wilting point pressure head $\left(<\mathrm{h}_{4}\right)$. Volumetric soil-water contents corresponding to those root-water uptake parameters are $0.445,0.232$, and $0.136 \mathrm{~cm}^{3} \mathrm{~cm}^{-3}$, respectively, for sweet corn crop and for the clay loam soil texture, using the van-Genuchten-Mualem relationship (van Genuchten, 1980). Soil-water storages corresponding to these values and changes over time, in observed SWS, are jointly plotted for the purpose of comparison.

The fresh marketable product was harvested at the milky stage, with seed-water content of about $70-75 \%$ occurring 100 days after sowing, for both cultivars and growing seasons. A $200 \mathrm{~cm}$ row length (10 plants) from the center of each plot was chosen. For both DS225 and DS225-T treatments, two adjacent rows corresponding to the nearest and the furthest rows from drip-line lateral were chosen to calculate the integrated measured parameters, and to assess row-torow variations for yields. Weight, length, and diameter of all husked cob with well-filled grains and longer than $10 \mathrm{~cm}$ were measured. Aboveground, vegetative parts of selected plants were also gathered, and then oven dried at $70^{\circ} \mathrm{C}$ until constant mass was obtained for dry matter (DM) determination. The weight of husked cobs and vegetative parts were converted into unit area yields $\left(\mathrm{Mg} \mathrm{ha}^{-1}\right)$. Irrigation water use efficiency (IWUE, $\mathrm{kg} \mathrm{m}^{-3}$ ) was determined by dividing yield by irrigation water volume $\left(\mathrm{m}^{3}\right)$. IWUE was calculated for both husked cob yield (IWUE $\mathrm{hc}_{\mathrm{hc}}$ ) and DM yield (IWUE $\mathrm{dm}_{\mathrm{dm}}$ ).

The measured parameters were subjected to the analysis of variance, using the DSAASTAT addin (Onofri, 2007). A combined analysis of data over both tested years was performed according to Gomez \& Gomez (1984), in order to recognize the treatment whose average effect over years was high and stable. The mean comparison was done after combined analysis, using the least significant difference test (LSD) at the $5 \%$ probability.

\section{Results and Discussion}

There were no significant interactions between year and treatment, or between cultivar and crop row/ dripline lateral spacing. Therefore, the effects of tested factors on the measured parameters were averaged over both seasons (Table 2). Moreover, the analysis of variance showed that crop row/drip-line lateral spacing, but not the cultivar, significantly influenced the measured parameters. Although numerous factors affect the crop response, this indicates that the planting arrangement plays an important role on sweet corn production.

Soil-water storages in the rows next to drip-line laterals varied from one treatment to another, but still 
remained between SWS( $\left.\mathrm{h}_{2}\right)$ and SWS $\left(\mathrm{h}_{3}\right)$, where rootwater uptake is maximal (Figure 1). This indicated no water stress throughout the whole growing season for the closer rows. However, soil-water storages remarkably decreased at the distant rows in the DS225. From the $60^{\text {th }}$ day after planting on, their values soon went down below the lower limit of optimal range of root-water uptake, $\mathrm{SWS}\left(\mathrm{h}_{3}\right)$. The degree of water stress excessively increased during the reproductive stage towards the harvest, but without declining below the lowest limit SWS $\left(\mathrm{h}_{4}\right)$. This can be attributed to the spatially variable soil-water conditions under the drip irrigation, resulting in insufficient supply of water to the points of the root zone away from the drip-line lateral. However, when using triple rows with $225 \mathrm{~cm}$ drip-line lateral spacing (DS225-T), the irrigation maintained SWS under both the closest and furthest crop rows at a fairly constant and high level. These results with similar behavior, in both growing seasons, indicate that the DS225-T treatment adequately provided the crop water needs. Plants grown in triple-rows increased the speed of canopy closure and, consequently, reduced the water losses by soil evaporation. Similar findings were reported by previous works on sweet corn crop with twin-row production system (Mubarak, 2020).

The yield of both tested cultivars seemed to be similar in the treatments evaluated (Figure 2). Moreover, yield decreased as the distance between drip-line lateral and crop row increased in the single-row DS225, but not in the triple-row DS225-T treatment. In the DS225, the row-to-row yield variation was 61.7 and $67.9 \%$ for 'Silver Queen' and 'White Kokab' cultivars, respectively. Conversely, yield was found to decrease when the crop rows were moved closer to drip-line laterals in the triple-row DS225-T treatment. The

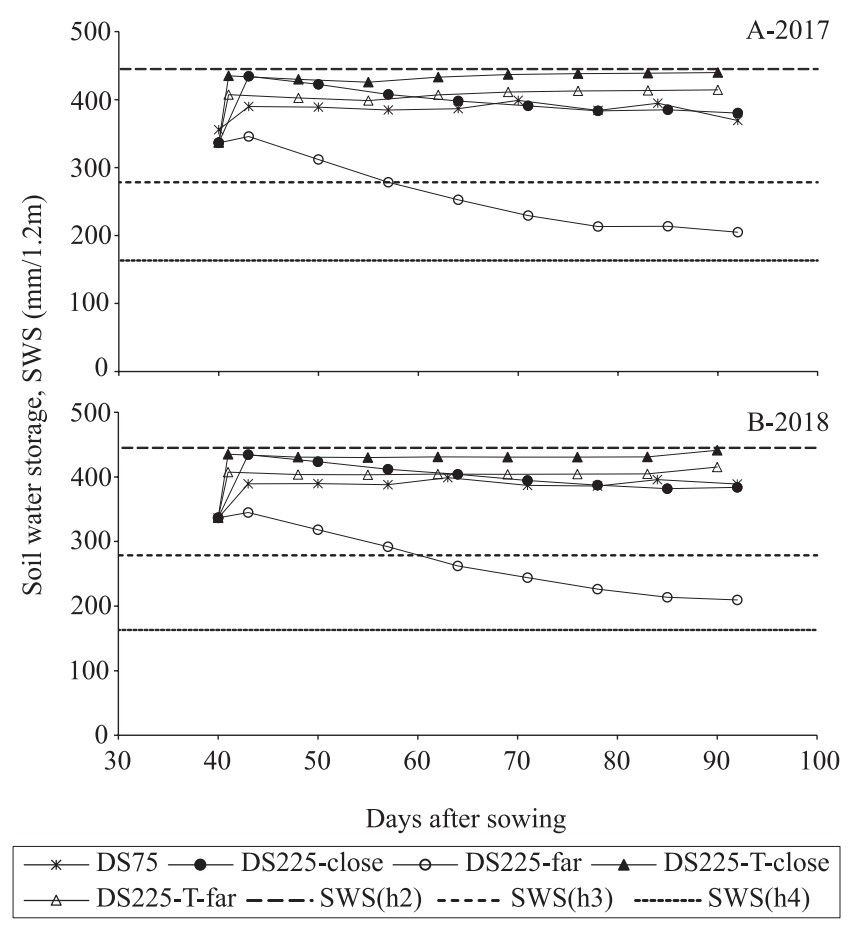

Figure 1. Changes over time in soil water storages in 120 $\mathrm{cm}$ soil profile for both growing seasons, respectively, for 'Silver Queen' cultivar. Dashed lines represent soil water storages at $h_{2}, h_{3}$, and $h_{4}$ corresponding to the root water uptake parameters for sweet corn crop as suggested by Feddes et al. (1978). DS75, DS225, and DS225-T represent treatments. 'Close' and 'far' represent the row next to the lateral and the distant row from the lateral, respectively.

Table 2. Mean comparisons of crop responses as function of both corn cultivar and crop row/lateral spacing ${ }^{(1)}$.

\begin{tabular}{|c|c|c|c|c|c|c|c|}
\hline Factor & $\begin{array}{l}\text { Husked cob } \\
\text { length }(\mathrm{cm})\end{array}$ & $\begin{array}{c}\text { Husked cob } \\
\text { diameter }(\mathrm{cm})\end{array}$ & $\begin{array}{l}\text { Husked cob } \\
\text { weight }(\mathrm{g})\end{array}$ & $\begin{array}{c}\text { Dry matter } \\
\text { yield }\left(\mathrm{Mg} \mathrm{ha}^{-1}\right)\end{array}$ & $\begin{array}{l}\text { Husked cob } \\
\text { yield }\left(\mathrm{Mg} \mathrm{ha}^{-1}\right)\end{array}$ & $\begin{array}{l}\operatorname{IWUE}_{\mathrm{dm}} \\
\left(\mathrm{kg} \mathrm{m}^{-3}\right)\end{array}$ & $\begin{array}{l}\operatorname{IWUE}_{\mathrm{hc}} \\
\left(\mathrm{kg} \mathrm{m}^{-3}\right)\end{array}$ \\
\hline \multicolumn{8}{|l|}{ Cultivar } \\
\hline Silver Queen & $18.0 \mathrm{a}$ & $4.6 \mathrm{a}$ & $236.4 \mathrm{a}$ & $8.49 \mathrm{a}$ & $11.51 \mathrm{a}$ & $1.17 \mathrm{a}$ & $1.59 \mathrm{a}$ \\
\hline White Kokab & $17.6 \mathrm{a}$ & $4.5 \mathrm{a}$ & $225.7 \mathrm{a}$ & $8.75 \mathrm{a}$ & $11.28 \mathrm{a}$ & $1.21 \mathrm{a}$ & $1.55 \mathrm{a}$ \\
\hline $\mathrm{LSD}_{0.05}$ & 1.05 & 0.1 & 29.7 & 0.67 & 1.40 & 0.09 & 0.19 \\
\hline \multicolumn{8}{|c|}{ Crop row/lateral spacing } \\
\hline DS75 & $18.8 \mathrm{a}$ & $4.8 \mathrm{a}$ & $244.3 \mathrm{a}$ & $8.07 \mathrm{~b}$ & $13.75 \mathrm{a}$ & $1.11 \mathrm{~b}$ & $1.89 \mathrm{a}$ \\
\hline DS225 & $15.8 \mathrm{~b}$ & $4.2 \mathrm{c}$ & $223.4 \mathrm{a}$ & $8.32 b$ & $8.92 \mathrm{c}$ & $1.15 b$ & $1.23 \mathrm{c}$ \\
\hline DS225-T & $18.6 \mathrm{a}$ & $4.7 \mathrm{~b}$ & $225.4 \mathrm{a}$ & $9.46 \mathrm{a}$ & $11.51 \mathrm{~b}$ & $1.30 \mathrm{a}$ & $1.59 \mathrm{~b}$ \\
\hline $\mathrm{LSD}_{0.05}$ & 0.8 & 0.1 & 23.1 & 0.80 & 1.00 & 0.11 & 0.13 \\
\hline
\end{tabular}

(1)In each column and for each tested factor, means followed by different letters are significantly different according to LSD test at $5 \%$ level. $I W U E_{d m}=$ irrigation water use efficiency for dry matter, and IWUE $E_{\mathrm{hc}}=$ irrigation water use efficiency for husked cob yield. 
exterior rows produced 21.1 and $23.7 \%$ more than the interior ones in 'Silver Queen' and 'White Kokab', respectively. Furthermore, the husked cob yield of interior rows (rows located next to drip-line laterals) in DS225 was higher than those of DS75 and DS225-T at 14.2 and $49.6 \%$, respectively (Figure 2).

These row-to-row variations were associated with the spatially variable soil-water conditions under the drip irrigation method. In plots with wider drip-line lateral spacing in single rows, the furthest crop rows were more water stressed than rows adjacent to the drip-line lateral, but not in the triple rows (Figure 1). These results are in agreement with those of Lamm et al. (1997), who reported that the row-to-row variation in corn crop could reach more than 67 and $41 \%$ for 230 and $300 \mathrm{~cm}$ lateral spacing, respectively. These yield losses could attain 95\% under deficit irrigation conditions. Nonetheless, Bozkurt et al. (2006) documented that corn yield from the $210 \mathrm{~cm}$ lateral spacing was only 8.2 and $9.6 \%$ lower than that of $140 \mathrm{~cm}$ lateral spacing for the closest and furthest crop rows, respectively. In addition, Murley et al. (2018) found that integrated corn crop yield was not affected by the distance between crop row and lateral, because the closer rows compensated the yield losses in distant rows.

For DMyield and IWUE $\mathrm{dm}_{\mathrm{dm}}$, no significant differences were found between DS75 and DS225 (Table 2). However, when rows were brought closer under the triple-row treatment, both parameters considerably enhanced, and recorded the highest values, whatever the tested corn cultivar. As well, both the mean value of husked cob yield and $\mathrm{IWUE}_{\mathrm{hc}}$ significantly decreased, as the drip-line lateral spacing increased in both single- and triple-row treatments. The maximum values were found in the conventional treatment DS75. The mean value in DS225 was severely reduced by about $35 \%$. Nevertheless, both parameters' losses were significantly attenuated to only about $16 \%$. However, no yield advantage of triple-rows over the conventional $75 \mathrm{~cm}$ rows were observed. This could be related to yield losses in plant rows next to the drip-line laterals due to excess irrigation. This result well agreed with the findings of Nafziger (2006), for whom, the early, higher-light interception in twin rows, compared with the $75 \mathrm{~cm}$ rows, did not contribute to the increase of

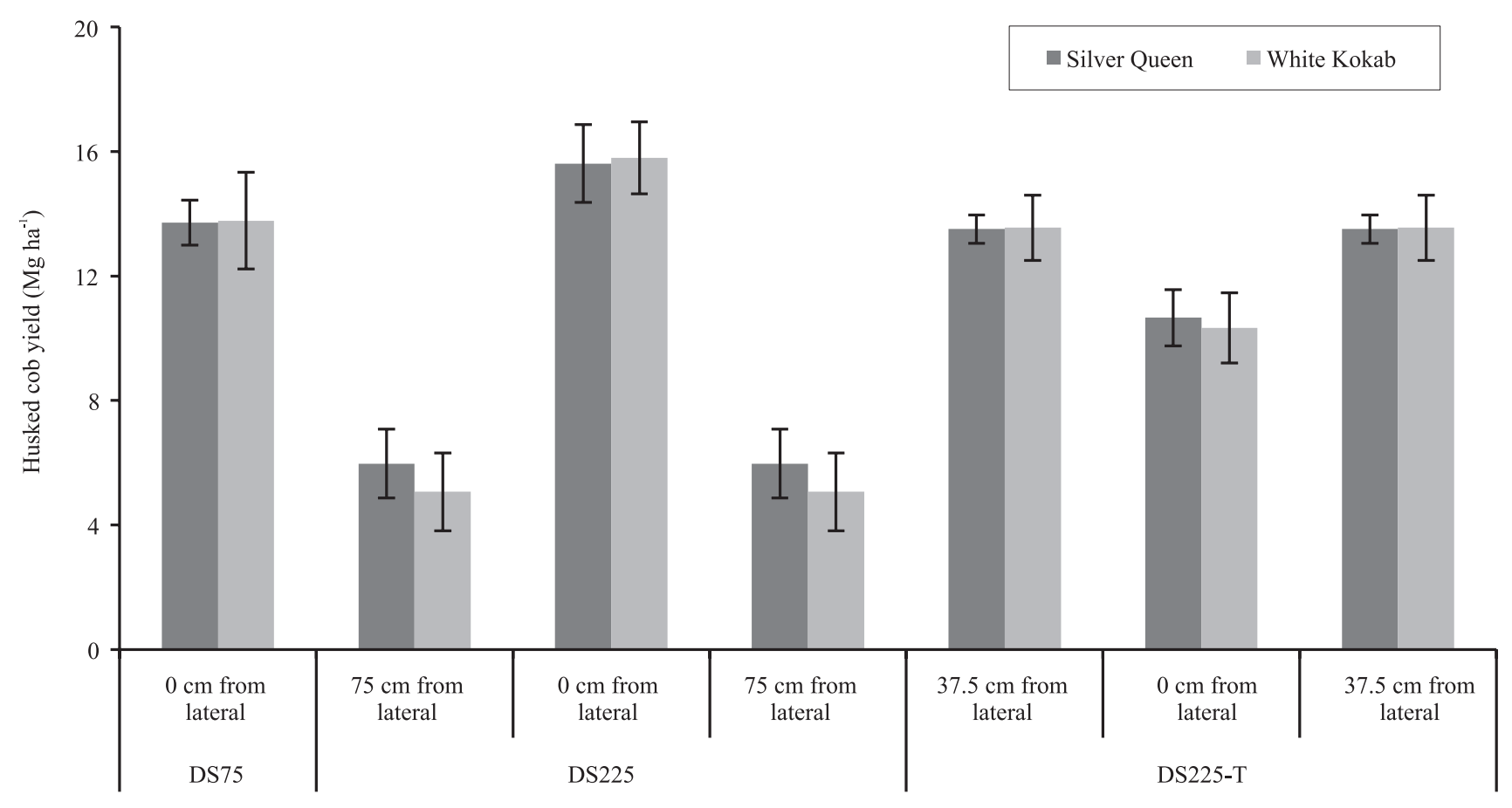

Figure 2. Husked cob yield distribution according to the distance from lateral for the combined data of both growing seasons, and for both tested cultivars. Individual crop row yields are mirrored about the lateral in each treatment for display purposes. DS75, DS225, and DS225-T represent treatments. Error bars represent the standard deviations. 
light interception during the grain filling stage and, therefore, to a higher production.

The enhancements of both yields and IWUEs obtained in triple-rows could be related to the enhanced status of soil-water in the root zone. This more convenient soil-water status in the triple-row treatment may stimulate roots to grow up and to consume more nutrients. Muhumed et al. (2014) indicated that the soil-water deficit reduces the uptake of macronutrients and, therefore, limits the sweet corn growth, but the full irrigation enables the roots to absorb the required nutrients from the soil. Moreover, Santos et al. (2018) cited that nutrients reach roots by mechanisms directly related to the water availability in the soil; therefore, sweet corn expresses its maximum production potential in a favorable soil-water status. In addition, the speed of canopy closure in triple rows improved the light interception, rising plant growth rates. Liu et al. (2011) report a similar result for corn crop grown in narrowwide planting patterns. The earlier canopy closure may reduce weeds and competition (Fanadzo et al., 2010; Saudy, 2013; Williams \& Boydston, 2013). As well, several studies reported similar mean yields, as that of Ertek \& Kara (2013), who reported $14.74 \mathrm{Mg} \mathrm{ha}^{-1}$ fresh cob yields of sweet corn, and the report by Mubarak (2020), who documented similar values of yields and IWUEs of both tested sweet corn cultivars in a twinrow production system. In a subsurface drip irrigation, mean corn yields were 13.6, 12.8, and $12.2 \mathrm{Mg} \mathrm{ha}^{-1}$ for 150,230 , and $300 \mathrm{~cm}$ lateral spacing, respectively (Lamm et al., 1997). However, mean corn yields were 8.57 and $8.92 \mathrm{Mg} \mathrm{ha}^{-1}$ for 70 and $210 \mathrm{~cm}$ lateral spacing, respectively, with a total irrigation depth of $750 \mathrm{~mm}$, as mentioned by Bozkurt et al. (2006). This indicates that the tested planting arrangement provides favorable growth conditions under which sweet corn crop shows its maximum yield potential.

Both length and diameter of husked cobs significantly decreased as drip-line lateral spacing increased in the single-row treatment. The traditional $75 \mathrm{~cm}$ treatment produced cobs considerably taller and larger by about 20 and $16 \%$, respectively, than those in DS225. However, a significant enhancement in husked cob size (length and diameter) could be obtained, when changing to the triple row treatment with $225 \mathrm{~cm}$ dripline lateral spacing, due to the enhancement of the soil-water status in the root zone, as above mentioned (Table 2). Although no research findings are available on sweet corn response to the same tested planting arrangement, some findings were reported for sweet corn crop by previous works. Mubarak (2020) reports similar values for both tested sweet corn cultivars, under single- and twin-row treatments, as follows: cob lengths between 17.5-18.8 cm; cob diameters between 4.8-4.9 cm; cob weights between 210-251 g. The 75 $\mathrm{cm}$ lateral spacing produced cobs considerably longer than those in the $150 \mathrm{~cm}$ lateral spacing with single rows, but, similar to those of the $150 \mathrm{~cm}$ lateral spacing with twin rows. Al-Hurmuzi \& Topak (2018) found no significant difference between two drip-line spacing of 70 and $140 \mathrm{~cm}$ for weight and length of sweet corn husked cob. However, they found that the $70 \mathrm{~cm}$ spacing produced larger cobs, as compared with the $140 \mathrm{~cm}$ spacing, even in the twin-row treatment. For corn crop, Bozkurt et al. (2006) found no considerable effects of different drip-line lateral spacing (70, 140, and $210 \mathrm{~cm}$ ) on cob length.

For one hectare $\left(100 \times 100 \mathrm{~m}^{2}\right)$, about $13,334 \mathrm{~m}$ of drip-line laterals are needed, when the current lateral spacing $75 \mathrm{~cm}$ is used. However, one third of this quantity (about 4,445 m) is only needed for one hectare, if the $225 \mathrm{~cm}$ lateral spacing is used. In other words, the $225 \mathrm{~cm}$ drip-line lateral spacing provides $66.7 \%$ less lateral quantity per unit area. The yield loss in the triple-rows with $225 \mathrm{~cm}$ drip-line lateral spacing was only $16 \%$, and it did not seem to be sufficient to justify an additional cost of a closer drip-line lateral spacing $(75 \mathrm{~cm})$. This in agreement with other published studies on multiple-row production systems (Lamm et al., 1997; Wang et al., 2014; Al-Hurmuzi \& Topak, 2018; Mubarak, 2020).

From the environmental point of view, reducing the drip-line lateral quantity per unit area to a third may reduce the quantity of related plastic fittings and the size of both main and submain pipes, reducing the harmful environmental impacts from damaged plastic pieces.

\section{Conclusions}

1. The yields of sweet corn (Zea mays) 'Silver Queen' and 'White Kokab' (a local cultivar), their cob characteristics, and irrigation water use efficiency are similar.

2. The water distribution in the $225 \mathrm{~cm}$ drip-line lateral spacing in single rows is not suitable for sweet 
corn production, even with the same quantity of irrigation water added.

3. Fresh cob yield and irrigation water use efficiency significantly decrease as drip-line lateral spacing increases; the nonuniformity of yield with the distance from the drip-line lateral negatively affects the total yield in single rows. However, both parameters are regained in the $225 \mathrm{~cm}$ lateral spacing when switching to the triple-row treatment.

4. The combined use of triple-rows with one dripline lateral per each triple-row represents an economic drip-irrigated planting pattern for the sustainable sweet corn crop production in the dry Mediterranean area.

\section{Acknowledgments}

To Atomic Energy Commission of Syria, for encouragement and support.

\section{References}

AL-HURMUZI, J.O.H.; TOPAK, R. Lateral spacing affect on yield and quality attributes of drip-irrigated sweet corn. Selcuk Journal of Agriculture and Food Sciences, v.32, p.55-59, 2018. DOI: https://doi.org/10.15316/SJAFS.2018.64.

ALLEN, R.G.; PEREIRA, L.S.; RAES, D.; SMITH, M. Crop evapotranspiration: guidelines for computing crop requirements. Rome: FAO, 1998. (FAO. Irrigation and Drainage Papers, 56).

BOZKURT, Y.; YAZAR, A.; GENCEL, B.; SEZEN, M.S. Optimum lateral spacing for drip-irrigated corn in the Mediterranean Region of Turkey. Agricultural Water Management, v.85, p.113-120, 2006. DOI: https://doi.org/10.1016/j.agwat.2006.03.019.

BRUNS, H.A. Planting date, rate, and twin-row vs. single-row soybean in the Mid-South. Agronomy Journal, v.103, p.13081313, 2011. DOI: https://doi.org/10.2134/agronj2011.0076.

BRUNS, H.A.; EBELHAR, M.W.; ABBAS, H.K. Comparing single-row and twin-row corn production in the Mid South. Crop Management, v.11, p.1-8, 2012. DOI: https://doi.org/10.1094/CM2012-0404-01-RS.

CHEN, R.; CHENG, W.; CUI, J.; LIAO, J.; FAN, H.; ZHENG, Z.; MA, F. Lateral spacing in drip-irrigated wheat: the effects on soil moisture, yield, and water use efficiency. Field Crops Research, v.179, p.52-62, 2015. DOI: https://doi.org/10.1016/j. fcr.2015.03.021.

COUTO, A.; RUIZ PADÍN, A.; REINOSO, B. Comparative yield and water use efficiency of two maize hybrids differing in maturity under solid set sprinkler and two different lateral spacing drip irrigation systems in León, Spain. Agricultural Water Management, v.124, p.77-84, 2013. DOI: https://doi.org/10.1016/j. agwat.2013.03.022.
EHSANULLAH, K.J.; JAMIL, M.; GHAFAR, A. Optimizing the row spacing and seeding density to improve yield and quality of sugarcane. Crop \& Environment, v.2, p.1-5, 2011.

ERTEK, A.; KARA, B. Yield and quality of sweet corn under deficit irrigation. Agricultural Water Management, v.129, p.138-144, 2013. DOI: https://doi.org/10.1016/j.agwat.2013.07.012.

FANADZO, M.; CHIDUZA, C.; MNKENI, P.N.S. Effect of inter-row spacing and plant population on weed dynamics and maize (Zea mays L.) yield at Zanyokwe irrigation scheme, Eastern Cape, South Africa. African Journal of Agricultural Research, v.5, p.518-523, 2010

FEDDES, R.A.; KOWALIK, P.J.; ZARADNY, H. Simulation of field water use and crop yield. New York: J. Wiley \& Sons, 1978. 189p.

FISCHER, R.A.; MORENO RAMOS, O.H.; ORTIZ MONASTERIO, I.; SAYRE, K.D. Yield response to plant density, row spacing and raised beds in low latitude spring wheat with ample soil resources: an update. Field Crops Research, v.232, p.95-105, 2019. DOI: https://doi.org/10.1016/j.fcr.2018.12.011.

GOMEZ, K.A.; GOMEZ, A.A. Statistical procedures for agricultural research. $2^{\text {nd }}$ ed. New York: John Wiley \& Sons, 1984. 680p.

GOYAL, M.R. (Ed.). Sustainable micro irrigation: principles and practices. Oakville: Apple Academic Press, 2014. 506p. (Research Advances in Sustainable Micro Irrigation, 1). DOI: https://doi.org/10.1201/b17155.

GOYAL, M.R. (Ed.). Water and fertigation management in micro irrigation. Oakville: Apple Academic Press, 2015. 356p. Research Advances in Sustainable Micro Irrigation, 9). DOI: https://doi.org/10.1201/b18800.

HIMANSHU, S.K.; KUMAR, S.; KUMAR, D.; MOKHTAR, A. Effects of lateral spacing and irrigation scheduling on drip irrigated cabbage (Brassica Oleracea) in a semi arid region of India. Research Journal of Engineering Sciences, v.1, p.1-6, 2012.

JACKSON, M.L. Soil chemical analysis: advanced course. rev. $2^{\text {nd }}$ ed. Madison:University of Wisconsin, 1985.

KOTTEK, M.; GRIESER, J.; BECK, C.; RUDOLF, B.; RUBEL, F. World map of Köppen-Geiger climate classification updated. Meteorologische Zeitschrift, v.15, p.259-263, 2006. DOI: https://doi.org/10.1127/0941-2948/2006/0130.

LAMM, F.R.; STONE, L.R.; MANGES, H.L.; O’BRIEN, D.M. Optimum lateral spacing for subsurface drip-irrigated corn. Transaction of the ASAE, v.40, p.1021-1027, 1997. DOI: https://doi.org/10.13031/2013.21354.

LIU, T.; SONG, F.; LIU, S.; ZHU, X. Canopy structure, light interception, and photosynthetic characteristics under different narrow-wide planting patterns in maize at silking stage. Spanish Journal of Agricultural Research, v.9, p.1249-1261, 2011. DOI: https://doi.org/10.5424/sjar/20110904-050-11.

LV, Z.; DIAO, M.; LI, W.; CAI, J.; ZHOU, Q.; WANG, X.; DAI, T.; CAO, W.; JIANG, D. Impacts of lateral spacing on the spatial variations in water use and grain yield of spring wheat plants within different rows in the drip irrigation system. 
Agricultural Water Management, v.212, p.252-261, 2019. DOI: https://doi.org/10.1016/j.agwat.2018.09.015.

MANDAL, K.G.; THAKUR, A.K.; MOHANTY, S. Paired-row planting and furrow irrigation increased light interception, pod yield and water use efficiency of groundnut in a hot sub-humid climate. Agricultural Water Management, v.213, p.968-977, 2019. DOI: https://doi.org/10.1016/j.agwat.2018.12.018.

MUBARAK, I. The response of two drip-irrigated sweet corn varieties to the twin-row production system in the dry Mediterranean region. The Open Agriculture Journal, v.14, p.915, 2020. DOI: https://doi.org/10.2174/1874331502014010009.

MUHUMED, M.A.; JUSOP, S.; SUNG, C.T.B.; WAHAB, P.E.M.; PANHWAR, Q.A. Effects of drip irrigation frequency, fertilizer sources and their interaction on the dry matter and yield components of sweet corn. Australian Journal of Crop Science, v.8, p.223-231, 2014.

MURLEY, C.B.; SHARMA, S.; WARREN, J.G.; ARNALL, D.B.; RAUN, W.R. Yield response of corn and grain sorghum to row offsets on subsurface drip laterals. Agricultural Water Management, v.208, p.357-362, 2018. DOI: https://doi.org/10.1016/j.agwat.2018.06.038.

NAFZIGER, E.D. Inter- and Intraplant Competition in Corn. Crop Management, v.5, p.1-9, 2006. DOI: https://doi.org/10.1094/ CM-2006-0227-05-RV.

ONOFRI, A. Routine statistical analyses of field experiments by using an Excel extension. In: CONGRESSO NAZIONALE SOCIETÀ ITALIANA DI BIOMETRIA, 6., 2007, Pisa. La statistica nelle scienze della vita e dell'ambiente: proceedings. Pisa: SIB, 2007. p.93-96.

PHOCAIDES, A. Handbook on pressurized irrigation techniques. $2^{\text {nd }}$ ed. Rome: FAO, 2007.

QI, W.; ZHANG, Z.-Y.; WANG, C.; CHEN, Y.; ZHANG, Z.-M. CRACK CLOSURE AND FLOW REGIMES IN CRACKED CLAY LOAM SUBJECTED TO DIFFERENT IRRIGATION METHODS. Geoderma, v.358, art.113978, 2020. DOI: https://doi.org/10.1016/j.geoderma.2019.113978.
SANTOS, O.F.; LIMA, S.F.; PIATI, G.L.; BARZOTTO, G.R.; GAVA, R. Irrigation as an alternative to reduce damages caused by defoliation of sweet corn. Horticultura Brasileira, v.36, 341345, 2018. DOI : https://doi.org/10.1590/s0102-053620180309.

SAUDY, H.S. Easily practicable packages for weed management in maize. African Crop Science Journal, v.21, p.291-301, 2013.

VAN GENUCHTEN, M.TH. A closed-form equation for predicting the hydraulic conductivity of unsaturated soils. Soil Science Society of America Journal, v.44, p.892-898, 1980. DOI: https://doi.org/10.2136/sssaj1980.03615995004400050002x.

VENOT, J.-P.; KUPER, M.; ZWARTEVEEN, M. (Ed). Drip irrigation for agriculture: untold stories of efficiency, innovation, and development. London: Routledge, 2017. 358p. DOI: https://doi.org/10.4324/9781315537146.

WANG, R.; WAN, S.; KANG, Y.; DOU, C. Assessment of secondary soil salinity prevention and economic benefit under different drip-line placement and irrigation regime in northwest China. Agricultural Water Management, v.131, p.41-49, 2014. DOI: https://doi.org/10.1016/j.agwat.2013.09.011.

WILLIAMS II, M.M.; BOYDSTON, R.A. Crop seeding level: implications for weed management in sweet corn. Weed Science, v.61, p.437-442, 2013. DOI: https://doi.org/10.1614/WS-D-1200205.1

WONDATIR, S.; BELAY, Z. Effect of drip lateral spacing and irrigation amount on tomato and onion crops cum water productivity at kobo Girrana valley, Ethiopia. Black Sea Journal of Agriculture, v.3, p.120-127, 2020.

ZHOU, L.; FENG, H.; ZHAO, Y.; QI, Z.; ZHANG, T.; HE, J.; DYCK, M. Drip irrigation lateral spacing and mulching affects the wetting pattern, shoot-root regulation, and yield of maize in a sand-layered soil. Agricultural Water Management, v.184, p.114-123, 2017. DOI: https://doi.org/10.1016/j.agwat.2017.01.008.

ZHOU,L.;HE,J.; QI,Z.; DYCK,M.;ZOU,Y.;ZHANG, T.; FENG, $\mathrm{H}$. Effects of lateral spacing for drip irrigation and mulching on the distributions of soil water and nitrate, maize yield, and water use efficiency. Agricultural Water Management, v.199, p.190200, 2018. DOI: https://doi.org/10.1016/j.agwat.2017.12.028. 